\title{
Nesting of Eurasian Tree Sparrow Passer montanus in a nest of Red Kite Milvus milvus
}

\author{
Häckning av pilfink Passer montanus \\ $i$ ett bo av röd glada Milvus milvus
}

\author{
Klaudia Litwiniak iD \& Marcin Przymencki \\ Plater 24, 64-115 Święciechowa, Poland | kklitwiniak@gmail.com \& marcin.przymencki@wp.pl
}

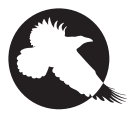

IN JUNE 2019 we found a nest of Eurasian Tree Sparrow Passer montanus in a nest of Red Kite Milvus milvus. It contained five chicks and was located on the side of the kite nest. The nests were located $17 \mathrm{~m}$ above ground in a pine tree in a small pine woodland within farmland in western Poland. We believe that this is the first record of Eurasian Tree Sparrow breeding in a Red Kite nest. Our observation supports the notion of great adaptability and flexibility in selection of nest site reported by other authors, who have found Eurasian Tree Sparrow nest in large twig nests of several species.

Keywords: nest site selection | predator protection | breeding ecology | passerine

While surveying birds of prey and Northern Raven Corvus corax within a study plot, we found a Eurasian Tree Sparrow Passer montanus nest in the foundation of a Red Kite nest. The kite nest was built in 2019 and was first observed on 2 May. On 23 June we visited the nest and ringed three almost fledged Red Kite young. During the ringing activities, we heard begging calls of passerine chicks. One of us (MP) found that the calls came from a nest with five young of Eurasian Tree Sparrow (Figure 1). The sparrow nest was located on the side of the kite nest and was padded with chicken feathers (Figure 2). We also observed adult Eurasian Tree Sparrows near their nest, but none of them was alarmed by our presence.

Our study plot is located in farmland in a postglacial landscape with many lakes in western Poland near Świerczyna village ( $\left.51^{\circ} 55^{\prime} \circ 8.3^{\prime \prime} \mathrm{N} 16^{\circ} 45^{\prime} 34.7^{\prime \prime} \mathrm{E}\right)$. Red Kites nest mainly in small midfield woods of pine or mixed tree species. The focal nest was located in a pine tree $17 \mathrm{~m}$ above the ground in a small pine woodland 


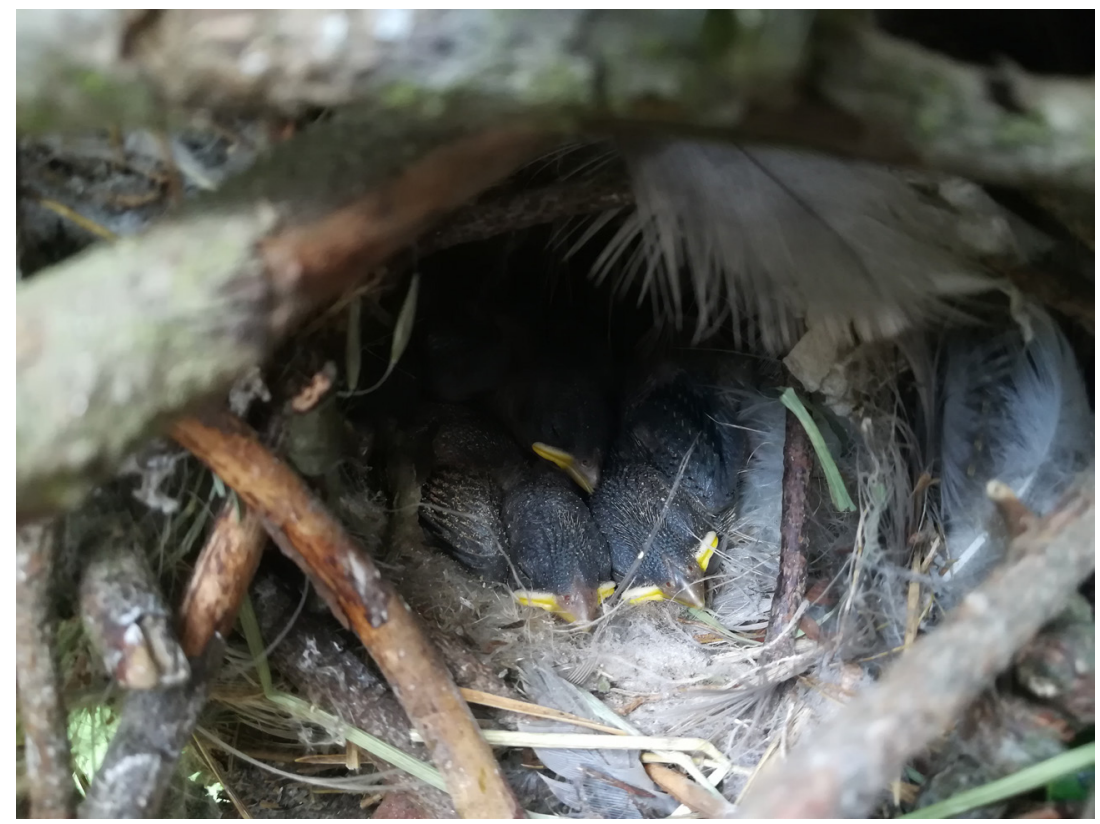

FIGURE 1. Nest with chicks of Eurasian Tree Sparrow Passer montanus in the foundation of a nest of Red Kite Milvus milvus. - Bo med ungar av pilfink Passer montanus i underlaget av ett bo av röd glada Milvus milvus.

$230 \mathrm{~m}$ from the nearest building. The outer diameter of the nest was $83 \mathrm{~cm}$ and the height $37 \mathrm{~cm}$.

The Eurasian Tree Sparrow breeds in open woodland, usually near cultivated land or human habitation (Cramp 1998). It is a secondary hole-nester, and the nesting sites are mainly tree holes, street lamps, nest boxes, buildings, rocky crevices and earth banks (Nankinov 1984, Cramp 1998, Węgrzynowicz 2012). Sometimes it occupies the foundations of disused or active nests of other birds, especially large twig nests.

Broods have been recorded in active nests of the following species: Barn Swallow Hirundo rustica, Eurasian Magpie Pica pica, Carrion Crow Corvus corone, Grey Heron Ardea cinerea (Seel 1964), White Stork Ciconia ciconia (Indykiewicz 1998, Bocheński 2005, Zbyryt et al. 2017), Common Buzzard Buteo buteo (Seel 1964, Szymański 2010), White-tailed Eagle Haliaeetus albicilla, Western Osprey Pandion haliaetus, and Black Kite Milvus migrans (Makatsch 1957, Cramp 1998).

Our observation adds another species to the list as we believe that it is the first nesting record of Eurasian Tree Sparrow in a Red Kite nest. Obviously, the Eurasian Tree Sparrow has high ecological adaptability and shows considerable flexibility in the selection of nest site.
Eurasian Tree Sparrows and other passerines may benefit from nesting in the nests of bigger birds by better securing the nests (Bocheński 2005), and occupying a nest of a bird of prey may provide decreased risk of egg and chick predation. Further, using the foundation of a larger nest as a nest location likely reduces energy expenditure for searching and carrying material for building (Indykiewicz 1998). In spite of those presumed benefits, reports of nesting within larger nests are uncommon, but a study of White Stork nests in NE Poland found passerines nesting within $57 \%$ of 233 stork nests, with no less than $37 \%$ of the stork nests containing nests of Eurasian Tree Sparrow (Zbyryt et al. 2017).

\section{References}

Bocheński M. 2005. Nesting of the sparrows Passer ssp. in the White Stork Ciconia ciconia nests in a stork colony in Kłopot (W Poland). International Studies on Sparrows 30: 39-41.

Cramp S. 1998. The Complete Birds of the Western Palaearctic on CD-ROM. Oxford University Press, Oxford.

Indykiewicz P. 1998. Breeding of House Sparrows Passer domesticus, Eurasian Tree Sparrow Passer montanus and Common Starling Sturnus vulgaris in the White Stork Ciconia ciconia nests. Notatki Ornitologiczne 39: 97-104. (In Polish.) 


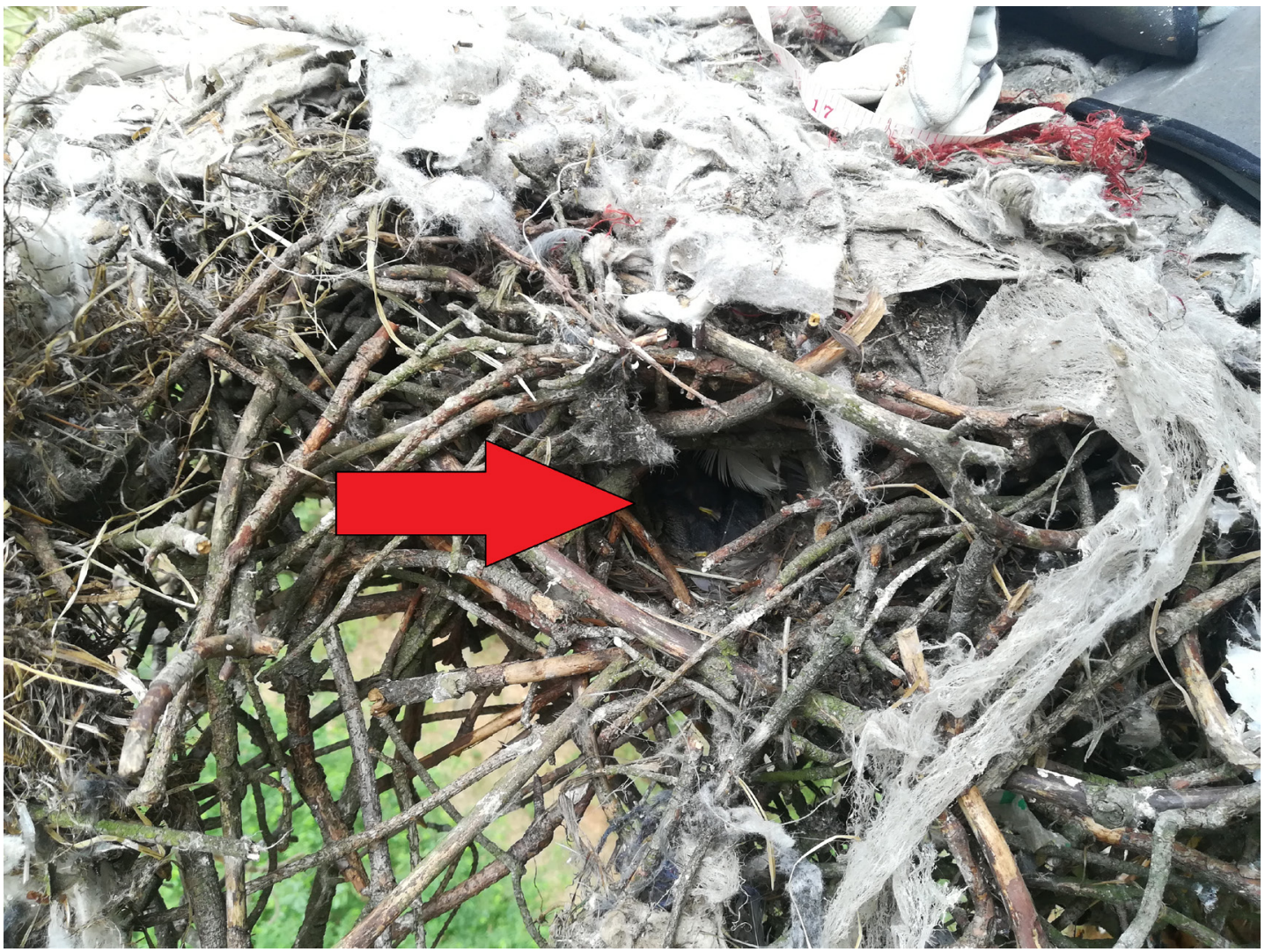

FIGURE 2. The location of the Eurasian Tree Sparrow Passer montanus nest in the Red Kite Milvus milvus nest. Photos: Marcin Przymencki. - Platsen för pilfinkboet Passer montanus i boet av röd glada Milvus milvus. Foton: Marcin Przymencki.

Makatsch W. 1957. Bird and nest, egg, nestling. PWN, Warszawa. (In Polish.)

Nankinov DN. 1984. Nesting habits of Tree Sparrow Passer montanus (L.) in Bulgaria. International Studies on Sparrows 11: 47-70. Seel DC. 1964. An analysis of the nest record cards of the Tree Sparrow Passer montanus. Bird Study 11: 265-271. https://doi. org/10.1080/00063656409476076

Szymański P. 2010. Nesting of Tree Sparrow Passer montanus in the nest of Common Buzzard Buteo buteo. International Studies on Sparrows 34: 25-26.

Zbyryt A, Jakubas D \& Tobolka M. 2017. Factors determining presence of passerines breeding within White Stork Ciconia ciconia nests. Science of Nature 104: 71. https://doi.org/10.1007/ soo114-017-1492-2

\section{Svensk sammanfattning}

I samband med ringmärkning av ungar av röd glada Milvus milvus i byn Świerczyna i västra Polen fann vi ett bo av pilfink Passer montanus i nedre kanten ett gladbo. Pilfinkboet innehöll fem ungar och bona fanns 17 meter upp i en tall i en liten talldunge i jordbrukslandskap. Vår observation av en pilfinkhäckning i ett bo av röd glada är förmodligen den första. Tidigare har häckning rapporterats i stora risbon av flera andra fågelarter. Dessa observationer visar att pilfinken är anpassningsbar och har stor flexibilitet i valet av boplats.

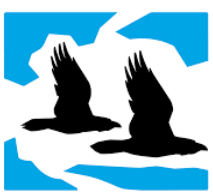

Birdlife Sverige

Ornis Svecica (ISSN 2003-2633) is an open access, peer-reviewed scientific journal published in English and Swedish by BirdLife Sweden. It covers all aspects of ornithology, and welcomes contributions from scientists as well as non-professional ornithologists. Accepted articles are published at no charge to the authors. Read papers or make a submission at https://os.birdlife.se.

Ornis Svecica (ISSN 2003-2633) är en fritt tillgänglig granskad vetenskaplig tidskrift som ges ut på svenska och engelska av BirdLife Sverige. Den täcker ornitologins alla områden och välkomnar bidrag från såväl forskare som icke-professionella ornitologer. Accepterade uppsatser publiceras utan kostnad för författarna. Läs uppsatser eller skicka in ditt bidrag på https://os.birdlife.se. 